\title{
Evaluation of Material Characteristics of Xylite - Part 2. Characterization of Drying Defects
}

\section{Procjena obilježja ksilita - dio 2. Karakterizacija grešaka sušenja}

\author{
Original scientific paper • Izvorni znanstveni rad \\ Received-prispjelo: 8. 2. 2013. \\ Accepted-prihvaćeno: 6. 2. 2014. \\ UDK: $630 * 812 ; 630 * 814.8 ; 630 * 852.3$ \\ doi:10.5552/drind.2014.1310
}

\begin{abstract}
Xylite very much has the appearance of precious wood species with dark heartwood and also has some physical and aesthetical properties of wood, required nowadays for making valuable products. Xylite, with well recognizable and preserved wood structure, was used for studying the drying kinetics and drying quality. The drying experiments were carried out at $20^{\circ} \mathrm{C}$ and $40{ }^{\circ} \mathrm{C}$ using constant relative air humidity ranging from $34 \%$ to $87 \%$, on elements $6 \mathrm{~mm}, 12 \mathrm{~mm}$ and $18 \mathrm{~mm}$ thick. The visual assessment of the drying quality was additionally made by light microscopy fracture analysis. The drying time increased with the increase of relative humidity and thickness of specimens. The yield of dry material decreased with the increase of drying time and with the increase of specimen thickness. End-splitting and bowing were the most common drying defects on tangentially oriented specimens. The failure usually occurred in collapsed earlywood, in disoriented tissue or in places with soil or mineral inclusions.
\end{abstract}

Keywords: xylite, drying, drying defects, drying time, microscopy

SAŽETAK • Ksilit izgledom podsjeća na dragocjene vrste drva tamne srži i još posjeduje relevantna fizikalna $i$ estetska svojstva drva koja su poželjna za izradu vrijednih proizvoda. Na uzorcima ksilita dobro vidljive i očuvane strukture drva istraživana je kinetika sušenja i kvaliteta osušenih elemenata. Eksperimenti sušenja izvedeni su s elementima ksilita debljine 6,12 i $18 \mathrm{~mm}$, pri temperaturama 20 i $40{ }^{\circ} \mathrm{C}$ u intervalu relativne vlažnosti zraka od 34 do $87 \%$. Vizualna procjena kvalitete dodatno je ispitana primjenom frakturne analize i svjetlosnog mikroskopa. Vrijeme sušenja produžavalo se s povećanjem relativne vlažnosti zraka i debljine elemenata, a kvalitativno iskorištenje materijala smanjivalo se s produljenjem vremena sušenja i s povećanjem debljine elemenata. Glavne greške sušenja bile su čeone pukotine i uzdužno zakrivljenje tangencijalno orijentiranih uzoraka. Najčešće mjesto grešaka sušenja bilo je kolabirano rano drvo, na mjestima velike dezorijentacije vlakanaca te tkiva s mineralnim $i$ zemljanim inkluzijama. Savijanje osušenih uzoraka ksilita dodatno se pripisuje povećanju gustoće tog materijala.

Ključne riječi: ksilit, sušenje, greške sušenja, vrijeme sušenja, mikroskopija

\footnotetext{
${ }^{1}$ Authors are professor and assistant professor at University of Ljubljana, Biotechnical Faculty, Department of Wood Science and Technology, Ljubljana, Slovenia.

${ }^{1}$ Autori su profesor i docent Odjela za znanost o drvu i drvnu tehnologiju, Biotehnički fakultet Sveučilišta u Ljubljani, Ljubljana, Slovenija.
} 


\section{INTRODUCTION}

\section{UVOD}

The Velenje lignite and xylite (as lithotype of lignite) seam is embedded approximately in the middle of the Plio-Pleistocene succession (Markič and Sachenhofer, 2010). During a long period of time, wood structure undergoes a drastic biochemical, geochemical and geological transformation, as well as carbonization (Drovenik, 1982; Justin and Markič, 2005). Anyway, it still retains some physical and mechanical behaviour of wood from which it originates (Gorišek et al., 2012; Gorišek and Straže, 2103). Still well preserved xylem structure may have a potential for use in some specific, often highly valuable end products. The research is a continuing attempt to convert low grade xylite into products of higher quality and more added value, as energy source, compared to primarily used briquetting and gasification (Anon., 2005; Gorišek, 2007).

When xylite does not contain great amounts of mineral inclusions, it can be processed with wood working machines. Especially when polished, it often shows recognizable structure of wood and its colour resembles to wood species with dark coloured heartwood, like wenge (Milletialaurentii) or ebony (Dyospiros sp.). The unpleasant fact is that xylite retains the worst characteristic of wood. Xylite remains hygroscopic; therefore, if it is to be used in normal climatic conditions, it should be dried to the appropriate moisture content that can ensure dimensional stability during use. Therefore, during the drying process, a large amount of bound water should be removed. Due to high density, the diffusion process in xylite is very slow, shrinkage is pretty high and a significant reduction of strength is expected. In this case, the drying needs to be considered as a low-stress loading of xylite, due to moisture content changes and drying gradient that cause high risk of warping and cracking in the process of drying or during exposure to changing climatic conditions.

The main aim of this research was to study the feasibility of conventional drying of xylite and the drying conditions affecting the kinetics of the procedure and the end product quality. Furthermore, typical drying defects were classified and the main causes were evaluated at the microscopic level of xylite structure.

\section{MATERIAL AND METHODS}

\section{MATERIJAL I METODE}

For the study, individual pieces of xylite were selected from the regular production line of lignite mine. Strong heterogeneity and large variability of xylite required visual assessment of material to select the pieces with the best preserved and recognizable wood structures.

For drying, specimens of three thicknesses (6 $\mathrm{mm}, 12 \mathrm{~mm}$ and $18 \mathrm{~mm}$ ) were cut and sorted according to the material density and colour assessment.

The drying process was carried out in thermostatically controlled chambers at two temperature lev- els $\left(T_{1}=20{ }^{\circ} \mathrm{C}\right.$ and $\left.T_{2}=40{ }^{\circ} \mathrm{C}\right)$. The different drying potentials were achieved by constant climatic conditions with four saturated salt solutions $\left(\mathrm{RH}_{1}=34 \%\right.$ $\left(\mathrm{MgCl}_{2}\right), \mathrm{RH}_{2}=65 \%\left(\mathrm{NaNO}_{2}\right), \mathrm{RH}_{3}=75 \%(\mathrm{NaCl})$ and $\left.\mathrm{RH}_{4}=86 \%\left(\mathrm{ZnSO}_{4}\right)\right)$, while for the drying at the highest temperature $\left(T_{2}\right)$, just two climatic conditions were used $\left(\mathrm{RH}_{2}=61 \%\left(\mathrm{NaNO}_{2}\right), \mathrm{RH}_{4}=84 \%\left(\mathrm{ZnSO}_{4}\right)\right)$. The average air velocity at the entry of the stack of $1.0 \mathrm{~m} / \mathrm{s}$ was achieved by radial fans.

The final quality control of dried xylite included the evaluation and macroscopic characterization of internal and external xylite cracking and possible geometrical changes like warping and anisotropic shrinkage. Microscopic characterization, including fracture and anatomy analysis, followed afterwards, and it was carried out using standard transmittance light microscopy techniques and differential colour staining. The yield of volume without damages was used for assessing the quality of dried xylite.

In order to determinate and describe the defects, the criteria were established for evaluating the defect on transverse and longitudinal sections. The transverse sections were evaluated by:

- presence of inclusions (minerals, soil);

- type and direction of cracks (orientation: radial, tangential, other) and their occurrence (earlywood, latewood, in the middle lamella or in the cell walls);

- assessment and extent of cracks (length - width);

- consistence of earlywood (appearance of tissue, presence of cracks and inclusions; degree of collapsed tissue);

- width of early and late wood and its proportion;

- number of cells in a radial series;

- shape and appearance of cells (e.g. cell wall thickness, number of layers in the cell wall, presence of radial cracks in the cell wall, depth of radial cracks in the cell walls) and

- degree of collapsing.

The longitudinal sections were additionally estimated by:

- occurrences of helical indentations and cracks;

- presence of slip panes and fractures, also other types of cracks;

- size and quantity of parenchyma tissue and

- presence of other inclusions.

\section{RESULTS AND DISCUSSION} 3. REZULTATI I RASPRAVA

The drying of xylite started from the average initial moisture content of $43.3 \%$ to the final moisture content $\left(M C_{\mathrm{f}}\right)$ achieved with equilibrium moisture content upon exposure to individual climatic conditions. The lowest $M C_{\mathrm{f}}$ was reached at $T=20{ }^{\circ} \mathrm{C}$ and $34 \%$ $R H$, namely $8.0 \%$, whereas the highest $M C_{\mathrm{f}}$ of $25.0 \%$ was attained in the most humid climatic conditions $\left(\mathrm{RH}_{4}=87 \%\right)$ (Gorišek et al., 2013).

The drying time depended on the drying conditions, as well as on thickness of individual specimens (Tab. 1). 
Table 1 Drying time of xylite at different drying regimes

Tablica 1. Vrijeme sušenja ksilita pri različitim uvjetima

\begin{tabular}{|l|c|c|c|c|c|c|}
\hline $\begin{array}{l}\text { Drying time, h } \\
\text { Vrijeme sušenja, } h\end{array}$ & \multicolumn{3}{|c|}{ Drying temperature / Temperatura sušenja } & \multicolumn{2}{c|}{$\begin{array}{c}\text { Drying temperature } \\
\text { Temperatura sušenja } \\
T_{1}=20{ }^{\circ} \mathrm{C}\end{array}$} \\
\hline $\begin{array}{l}\text { Thickness } \\
\text { Debljina }\end{array}$ & $\varphi=34 \%$ & $\varphi=65 \%$ & $\varphi=75 \%$ & $\varphi=86 \%$ & $\varphi=61 \%$ & $\varphi=84 \%$ \\
\hline$d=6 \mathrm{~mm}$ & 190.2 & 381.6 & 502.0 & 857.6 & 72.0 & 194.4 \\
\hline$d=12 \mathrm{~mm}$ & 285.4 & 453.3 & 526.8 & 888.1 & 105.1 & 262.5 \\
\hline$d=18 \mathrm{~mm}$ & 474.2 & 507.3 & 583.8 & 936.4 & 207.3 & 376.1 \\
\hline
\end{tabular}

The dependency of the drying process time and specimen thickness is well correlated and can be successfully fitted to the exponential regression model. Generally, drying at the normal climatic conditions (20 ${ }^{\circ} \mathrm{C} / 65 \%$ ) or drier climate resulted in a sufficiently short drying time, whereas lower drying potential was less successful. Comparison between the procedure duration and some known drying kinetics models (Simpson and Tschernitz, 1980, Bekhta et al., 2006, Trübswetter, 2006) confirmed a very low diffusion coefficient for the transport of bound water.

The results of final quality control of drying showed a low yield of xylite suitable for use for final products. Higher quality was obtained by drying in mild conditions and at lower temperature (Tab. 2), whereas it decreased with the increase of thickness of xylite specimens. This can be ascribed to assumed increase of drying stresses with thicker material, often found during drying of natural sawn wood (Hunter, 2002; Pang, 2002; Thuvander et al., 2002; Kang et al., 2004), and also due to a probably higher content of mineral and other inclusions in thicker specimens, not detected during visual inspection. Greater heterogeneity and disorientation of the investigated xylite structure could also cause more fractures in thicker xylite elements. Compared to the drying time at different time regimes, the yield of quality dried xylite is negatively correlated to the duration of the procedure (Tab. 1).

Table 2 The average yield of xylite specimens suitable for end use after drying at different regimes Tablica 2. Prosječan postotak iskoristivog ksilita nakon sušenja pri različitim uvjetima

\begin{tabular}{|l|c|c|c|c|c|c|}
\hline $\begin{array}{l}\text { Yield, \% } \\
\text { Iskorištenje, \% }\end{array}$ & \multicolumn{4}{|c|}{$\begin{array}{c}\text { Drying temperature / Temperatura sušenja } \\
T_{1}=20{ }^{\circ} \mathrm{C}\end{array}$} & \multicolumn{2}{c|}{$\begin{array}{c}\text { Drying temperature } \\
\text { Temperatura sušenja } \\
T_{2}=40{ }^{\circ} \mathrm{C}\end{array}$} \\
\hline $\begin{array}{l}\text { Thickness } \\
\text { Debljina }\end{array}$ & $\varphi=34 \%$ & $\varphi=65 \%$ & $\varphi=75 \%$ & $\varphi=86 \%$ & $\varphi=61 \%$ & $\varphi=84 \%$ \\
\hline$d=6 \mathrm{~mm}$ & 55.5 & 70.0 & 61.0 & 67.0 & 60.1 & 61.5 \\
\hline$d=12 \mathrm{~mm}$ & 43.1 & 65.0 & 51.0 & 60.0 & 60.7 & 64.3 \\
\hline$d=18 \mathrm{~mm}$ & 45.5 & 54.9 & 58.8 & 54.6 & 43.3 & 51.1 \\
\hline
\end{tabular}

The most common defects that reduce the quality and ability of exploitation of xylite were reflected in various types of cracks and different kind of warping.

End splitting and cleavage occurred more frequently in xylite than in some wood species (Chen et al., 1997; Oltean et al., 2007; Ratnasingam et al., 2010). Cracking of xylite mostly occurred in tangential direction. This is opposite to the usual checks of wood, where large tangential shrinkage induces radially oriented cracks typically at the junction of rays and longitudinally oriented fiber-form tissue (Oltean et al., 2007; Ratnasingam et al., 2010). In xylite, the transverse shrinkage anisotropy is not so marked and reaches the value of around 1.5 (Gorišek et al., 2012), which is considerable less than in most wood species (Dinwoodie, 2000). ). Therefore, the large difference in shrinkage is not between the radial and tangential direction but between more or less different structures of parallel layers (Fig. 1). Typical tangentially oriented cracks emerged on the border between often collapsed earlywood cells and better preserved latewood cells. In these locations, early-wood was often laying over latewood (Fig. 2). Delamination between earlywood and latewood in tangential plan can be ascribed to different shrinkage and different rigidity of cell walls in these two categories. 

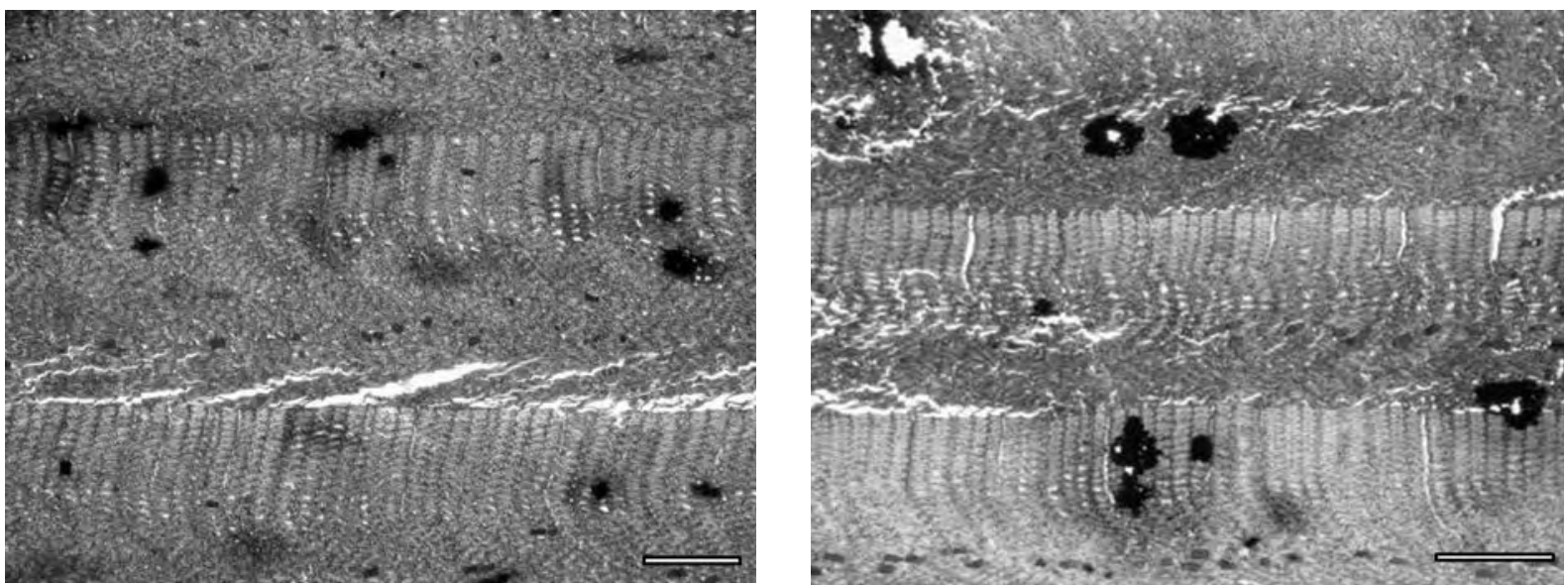

Figure 1 Cross-sections of xylite: Failures are most common in places with large differences in density and sharp transition from earlywood to latewood and in slip layers of earlywood (the shear strength of collapsed cell walls is weakened). Bars $-100 \mu \mathrm{m}$ Slika 1. Poprečni presjeci ksilita: pukotine se najčešće nalaze na mjestima velikih razlika gustoće i oštrog prijelaza iz ranog u kasno drvo te u posmaknutim slojevima ranog drva (čvrstoća smicanja urušenih staničnih stijenki smanjena je). Trake - $100 \mu \mathrm{m}$
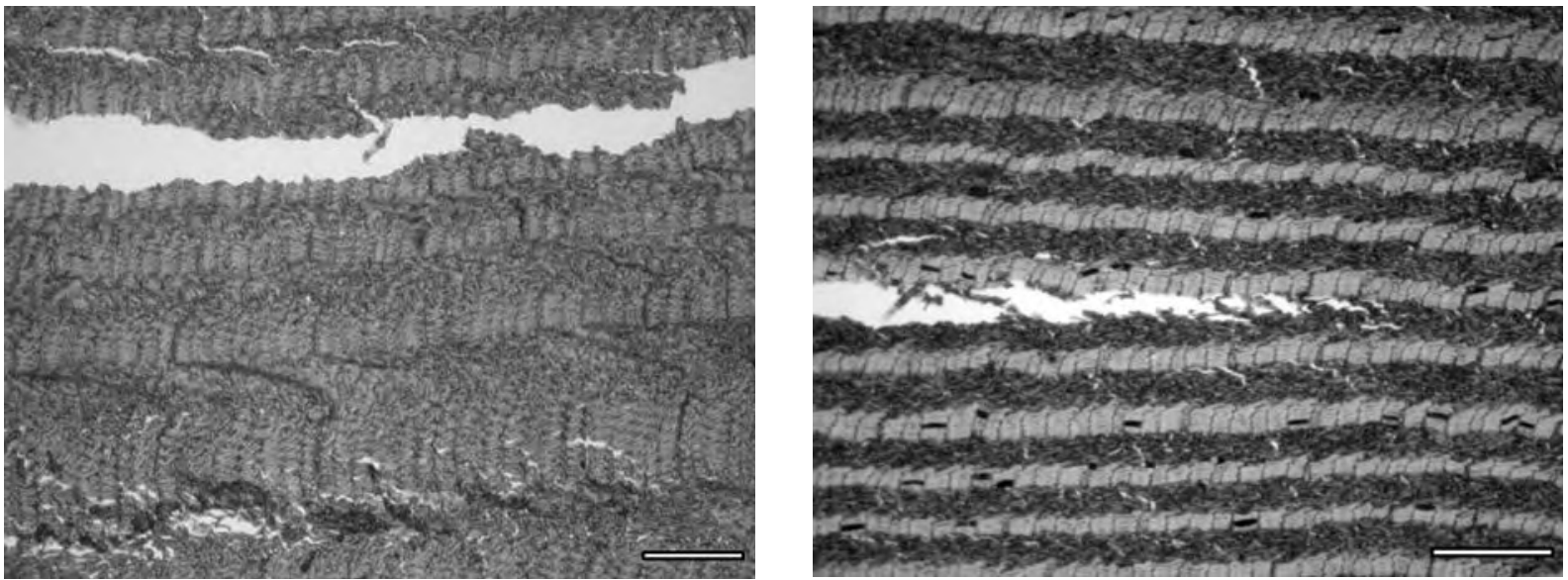

Figure 2 Cross-sections of xylite: Splitting caused by heavily disoriented tissue in intercalating and kneading fibers also weakened by soil and mineral inclusions. Bars $-100 \mu \mathrm{m}$

Slika 2. Poprečni presjeci ksilita: razdvajanje tkiva uzrokovano je vrlo dezorijentiranim staničjem u zgnječenim i umetnutim vlaknima koja su oslabljena inkluzijama minerala i zemlje. Trake - $100 \mu \mathrm{m}$

Failures are most common in places with large differences in density and sharp transition from earlywood to latewood as well as in slip layers of earlywood. Collapsed earlywood cell walls and slip layers in earlywood had very low shear strength (Fig. 3 and
Fig. 4). Mineral and soil inclusion mainly arranged in tangential directions are probably the next weakening factor of xylite tissue in this direction and a possible place for initiating the fracture (Fig. 5).

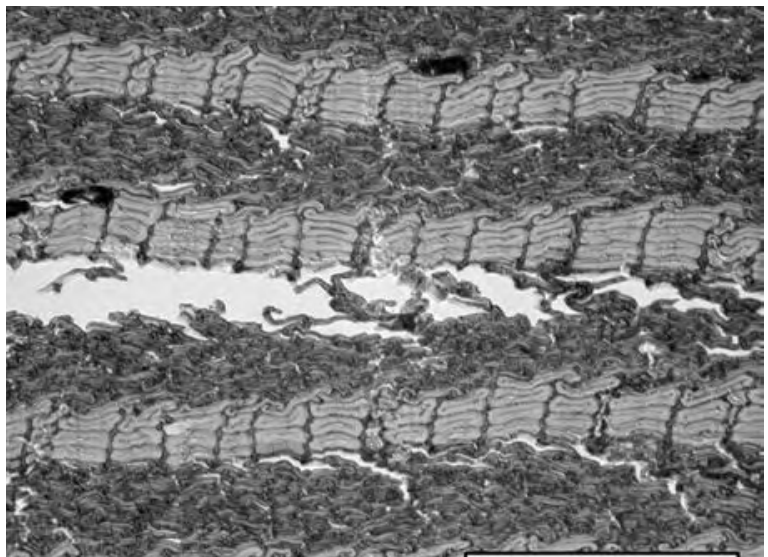

Figure 3 Cross-sections of xylite: End cracking is the result of large radial shrinkage, due to higher collapsing and densification of tissue in this direction. Bars $-100 \mu \mathrm{m}$

Slika 3. Poprečni presjeci ksilita: čeone su pukotine rezultat velikoga radijalnog utezanja zbog većeg urušavanja i povećanja gustoće tkiva u tom smjeru. Trake - $100 \mu \mathrm{m}$. 

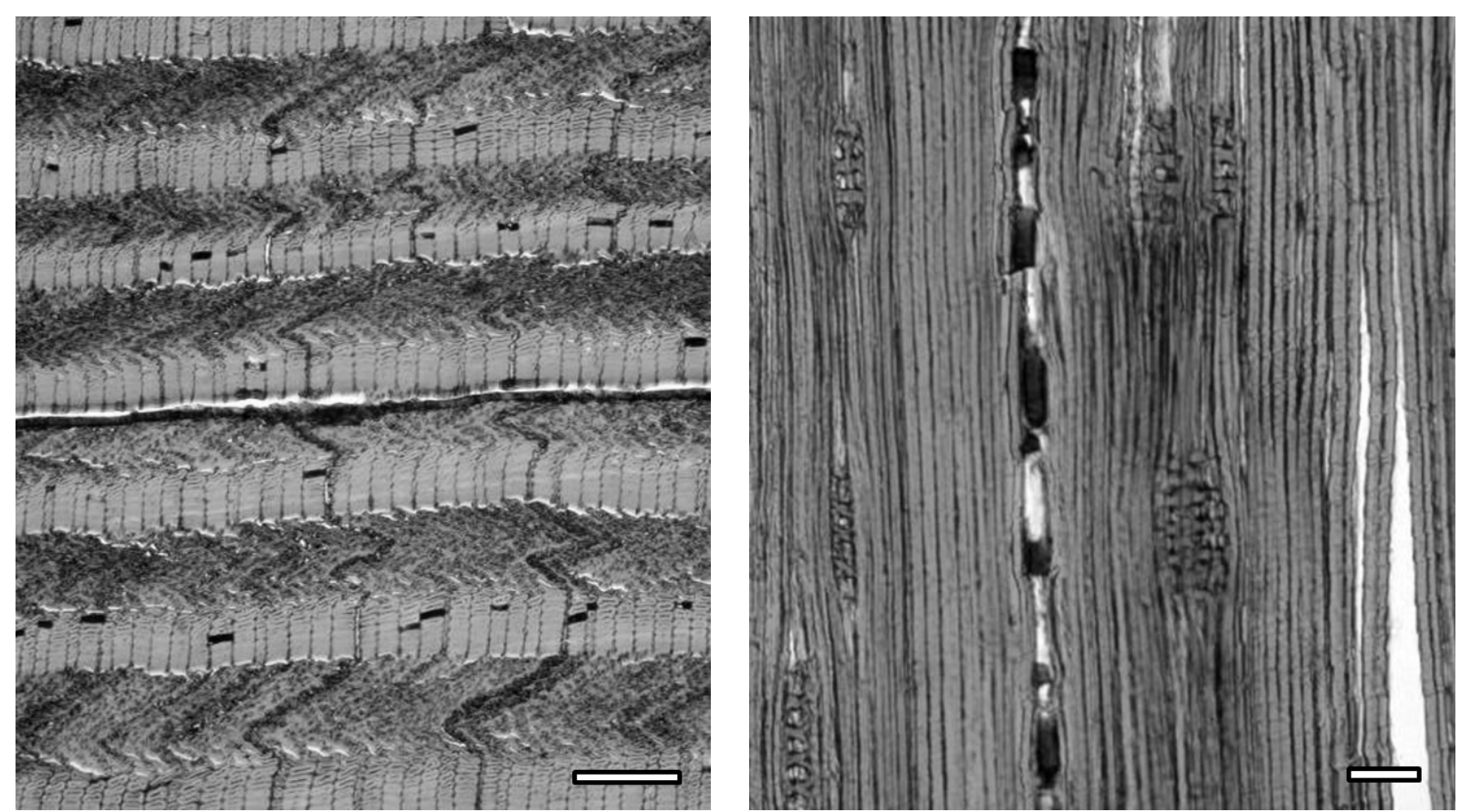

Figure 4 Cross-section (left) and tangential section (right) of xylite: Mineral and soil inclusions mainly arranged in tangential arches weaken the cohesion bonds between fibers. Bars $-100 \mu \mathrm{m}$

Slika 4. Poprečni presjek (lijevo) i tangencijalni presjek (desno) ksilita: inkluzije zemlje i minerala raspoređene u tangencijalnim lukovima oslabljuju kohezijske veze između vlakanaca. Trake - $100 \mu \mathrm{m}$.
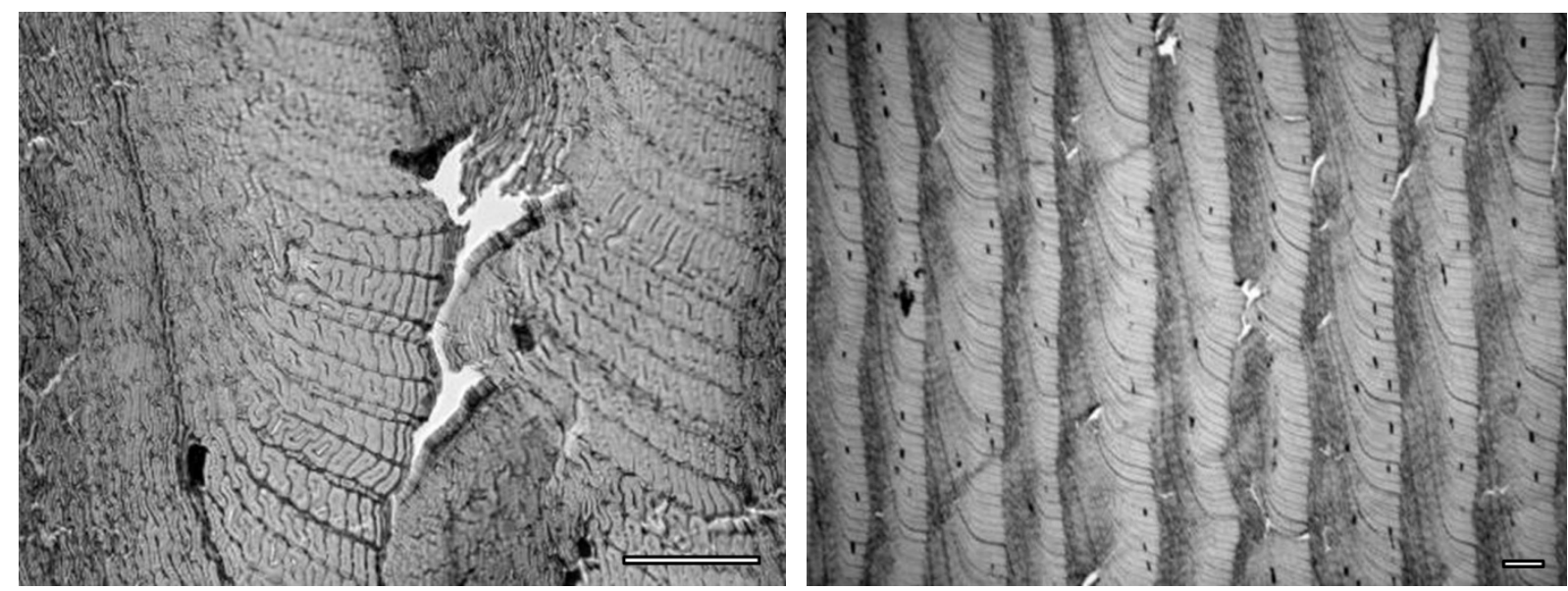

Figure 5 Cross-sections of xylite: Failure of cell walls and formation of slip planes are characteristic for earlywood. Bars $-100 \mu \mathrm{m}$ Slika 5. Poprečni presjeci ksilita: greške staničnih stijenki i stvaranje ravnina smicanja karakteristični su za rano drvo. Trake - $100 \mu \mathrm{m}$.
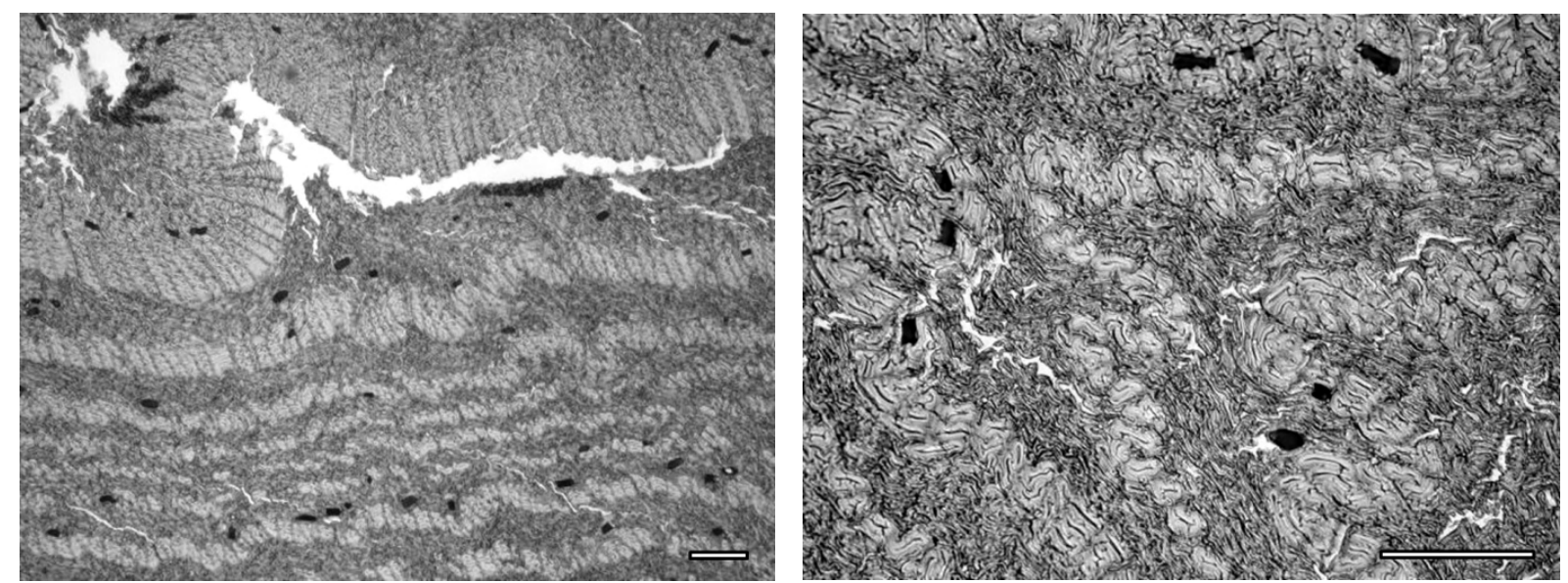

Figure 6 Cross-sections of xylite: Thinner pieces of xylite are subject to bowing and warping due to different orientation of layered structure and different overlying tissues. Bars $-100 \mu \mathrm{m}$

Slika 6. Poprečni presjeci ksilita: tanji komadi ksilita podvrgnuti su koritanju i krivljenju zbog različite orijentacije uslojene strukture te različitih staničja u preklapajućim slojevima. Trake - $100 \mu \mathrm{m}$. 
Since the average shrinkage of xylite along the grain is significantly larger than in nowadays wood species (Gorišek et al., 2012), the occurrence of warp in xylite is also more frequent than in wood. Xylite was less susceptible to side bending (crook) than to warping along the length of the element face (bow) (Fig. 6), and more susceptible to bowing in thinner elements.

The main factor influencing the degree of crooking or bowing in a sawn wood is usually the original location in the log (juvenile wood) or the presence of reaction wood (Gorišek and Straže, 2004; Straže et al. 2011). It is quite difficult to identify the reaction or even juvenile tissues in xylite. As it is certain that the influence of long-term geochemical conversion from wood into xylite was significantly greater than the differences between various categories of wood, xylite warping is considered to be caused by densification processes, damages and reorientation of tissue. The largest differences are observed between less altered latewood with more rigid cell walls and collapsed thin cell walls of earlywood. Warp also appeared in locations with heavily reoriented tissue caused by intruding and kneading of fibers. In many bow-deformed elements, overlaid tissues were recognized with characteristic interwoven microstructure.

\section{CONCLUSIONS}

4. ZAKLJUČAK

The drying kinetics of xylite is similar and even slower than the drying kinetics of very dense wood species with high internal resistance to moisture flow. Nevertheless, the use of low drying potential, i.e. high relative air humidity and low temperature, increases the yield of quality dried xylite suitable for some specific products after drying.

Collapsed structure of xylite and its considerably reduced strength and dimensional stability were the main risks and defects during the drying process. Heterogeneity and presence of mineral and soil inclusions also have an important role in the xylite structure, especially with thicker elements.

Investigation of drying defects on microscopic level showed that the cracks are more frequently oriented in tangential direction. Failures are most common in completely collapsed earlywood or between earlywood and latewood. From there, associated with the presence of huge tissue disorientation, the initiated fractures usually cause serious surface checking and most often characteristic end-splitting of dried elements. Warping of dried xylite specimens, more present with thinner elements, can be ascribed to high densification and to local reorientations of xylite structure, while the influence of juvenility or reaction tissues have to be excluded.

\section{Acknowledgement - Zahvala}

The material was obtained in the framework of the project: Proučevanje in raziskovanje ksilita Standardizacija mikrolitotipov lignita in njihova di- menzijska stabilizacija, co-founded by Premogovnik Velenje d.d., Slovenia.

\section{REFERENCES}

\section{LITERATURA}

1. Anon., 2005: Oblikovanje v ksilitu. Akademija za likovno umetnost. Velenje. $47 \mathrm{p}$.

2. Bekhta, P.; Ozarkiv, I.; Alavi, S.; Hiziroglu, S., 2006: A theoretical expression for drying time of thin lumber. Bioresource Technology, 97 (13): 1572-1577. http://dx.doi. org/10.1016/j.biortech.2005.06.005

3. Chen, Y.; Keey, R. G. B.; Walker, J. C. F., 1997: The drying stress and check development on high-temperature kiln seasoning of sapwood Pinus radiata boards. Holz als Roh- und Werkstoff, 55: 59-64. http://dx.doi. org/10.1007/BF02990517

4. Dinwoodie, J. M., 2000: Timber. Its nature and behaviour. BRE London \& New York. 257 p. http://dx.doi. org/10.4324/9780203477878

5. Drovenik, M., 1982: Nahajališča premogov. Ljubljana. Univerza Edvarda Kardelja v Ljubljani, Fakulteta za naravoslovje in tehnologijo: $120 \mathrm{p}$.

6. Gorišek, Ž., 2007: Ksilit - zamenjava za ebenovino? Korak (N. Gorica) 8, 5: 23-27.

7. Gorišek, Ž.; Čufar, K.; Straže, A., 2012: Charaterization of anatomical structure and basic physical properties of Velenje xylite. Zbornik gozdarstva in lesarstva. 98: 2738 .

8. Gorišek, Ž.; Straže, A., 2004: Influence of wood structure on warp in Norway spruce (Picea abise L.) during kiln drying. Ed. Jambreković, V.: Wood in construction industry - durability and quality of engineered wood. Zagreb Šumarski fakultet. 67-74.

9. Gorišek, Ž.; Straže, A., 2013: Evaluation of material characteristics of xylite - Part 1. Influence of moisture content on some mechanical properties. Drvna industrija 64(4): 305-312.

10. Hunter, A. J., 2002: Movement in a board of the impermeable wood during drying. Wood Science and Technology, 36: 27-40. http://dx.doi.org/10.1007/s00226-0010125-1

11. Justin, B.; Markič, M., 2005: Mikroskopska analiza velenjskega ksilita. Velenje, ERICo Velenje, Inštitut za ekološke raziskave: $22 \mathrm{p}$.

12. Kang, W.; Nam-Ho, L.; Hee-Suk, J., 2004: Simple analitical methods to predict one- and two-dimensional drying stresses and deformations in lumber. Wood Science and Technology, 38: 417-428. http://dx.doi.org/10.1007/ s00226-004-0230-z

13. Markič, M.; Sachenhofer, R. F., 2010: The Velenje lignite - Its petrology and genesis. Geološki zavod Slovenije, Ljubljana, $233 \mathrm{p}$.

14. Oltean, L.; Teischinger, A.; Hansmann, C., 2007: Influence of temperature on cracking and mechanical properties of wood during wood drying - A review. BioResources, 2 (4): 789-811.

15. Pang, S., 2002: Investigation of effects of wood variability and rheological properties on lumber drying: application of mathematical models. Chemical Engineering Journal, 86 (1-2): 103-110. http://dx.doi.org/10.1016/ S1385-8947(01)00278-9

16. Ratnasingam, J.; Grohmann, R.; Scholz, F., 2010: Drying quality of rubberwood: an industrial perspective. European Journal of Wood and Wood Products, 68 (1): 115- 116. http://dx.doi.org/10.1007/s00107-009-0353-x 
17. Simpson, W. T.; Tschernitz, J. L., 1980: Time, costs and energy consumption for drying red oak lumber as affected by thickness and thickness variation. Forest Products Journal, 30: 23-28.

18. Straže, A.; Kliger, R.; Johansson, M.; Gorišek, Ž., 2011: The influence of material properties on the amount of twist of spruce wood during kiln drying. Holz als roh and werkstof. 69 (2): 239-246. http://dx.doi.org/10.1007/ s00107-010-0422-1

19. Thuvander, F.; Kifetew, G.; Beglund, L. A., 2002: Modelling of cell wall stresses in wood. Wood Science and Technology, 36(3): 241-254. http://dx.doi.org/10.1007/ s00226-001-0134-0
20. Trübswetter, T., 2006: Holztrocknung: Verfahren zur Trocknung von Schnittholz - Planung von Trocknungsanlagen. Fachbuchverlag Laipzig, München, 204 p.

\section{Corresponding address:}

Assoc. Prof. ŽELJKO GORIŠEK, Ph.D.

University of Ljubljana, Biotechnical Faculty

Department of Wood Science and Technology

Rožna dolina, Cesta VIII/34

1000 Ljubljana, SLOVENIA

e-mail: zeljko.gorisek@bf.uni-lj.si 